\title{
Metamorfozy baśni i baśniowe metamorfozy
}

\author{
Bednarek, M. (2020). Baśni przeobrażone. Transformacje bajki \\ i baśni w polskiej epice po 1989 roku. WN UAM.
}

\section{Abstrakt:}

Artykuł recenzyjny poświęcony jest monografii Baśni przeobrażone. Transformacje bajki i baśni w polskiej epice po 1989 roku (2020). Jej autorka, Magdalena Bednarek, ukazuje potencjał baśni (ale też m.in. bajki zwierzęcej, bajki ludowej itd.) polegający na przenikaniu rozmaitych jej elementów do różnorodnych wymiarów utworu literackiego i specyficznym organizowaniu jego struktury oraz na konstruowaniu fabuł, sensów i postaci. Za materiał badawczy posłużyła Bednarek przede wszystkim proza realistyczna adresowana do dorosłych czytelników - funkcjonująca w różnych obiegach kulturowych - wydana w Polsce w ciągu ostatnich trzydziestu lat. W artykule poddano refleksji sposób doboru źródeł literackich przez autorkę oraz zastosowaną przez nią terminologię (m.in. „bajka” jako kategoria nadrzędna dla zróżnicowanych gatunków, „antybaśń”, „retelling”, „rewriting”). Przeanalizowano także trzy perspektywy, z których Bednarek rozpatrzyła (w dużej mierze w kontekście krytyki feministycznej) formy obecności baśni w rodzimej epice niebaśniowej: (1) gatunkowe metamorfozy baśni, (2) przekształcenia popularnych motywów i wątków, (3) przeobrażenia postaci (głównie bohaterek).

Słowa kluczowe:

antybaśń, bajka, baśń, feminizm, literatura polska po 1989 roku, Magdalena Bednarek, przeobrażenia, retelling, rewriting

* Weronika Kostecka - dr, pracuje w Instytucie Literatury Polskiej Wydziału Polonistyki na Uniwersytecie Warszawskim. Jej zainteresowania badawcze obejmują historię oraz teorię literatury dziecięcej i młodzieżowej, kulturową historię baśni oraz literaturę i kulturę popularną. Kontakt:w.kostecka@uw.edu.pl. 


\title{
Metamorphoses of Fairy Tales and Fairy-Tale Metamorphoses
}

\author{
Bednarek, M. (2020). Baśni przeobrażone. Transformacje bajki i baśni \\ w polskiej epice po 1989 roku. WN UAM.
}

\section{Abstract:}

The review article is devoted to the monograph Baśni przeobrażone. Transformacje bajki i baśni w polskiej epice po 1989 roku [Fairy Tales Transformed: The Metamorphosis of Fairy Tales in Polish Literature after 1989] (2020). Its author, Magdalena Bednarek, shows the potential of the fairy tale (but also the animal tale, the folktale, etc.), consisting in the penetration of its various elements into diverse dimensions of a literary work and the specific organisation of its structure, and the construction of plots, meanings, and characters. Bednarek's research material was, above all, realistic prose addressed to adult readers - functioning in various cultural circles - published in Poland over the last thirty years. The article reflects on the author's way of selecting literary sources and the applied terminology (including bajka as a superior category for diverse genres, 'anti-fairy tale,' 'retelling,' 'rewriting'). Three perspectives were also analysed from which Bednarek considered (largely in the context of feminist criticism) the forms of the presence of fairy tales in Polish realistic prose: (1) genre metamorphoses of fairy tales, (2) transformations of popular motifs, (3) transformations of characters (mainly heroines).

\section{Key words:}

anti-fairy tale, folktale, fairy tale, feminism, Polish literature after 1989, Magdalena Bednarek, transformations, retelling, rewriting

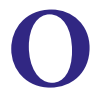

rozwijającej się w XXI wieku modzie na baśnie chyba nikogo nie trzeba przekonywać. Widoczna jest w rozmaitych obszarach kultury, ogłoszono ją tak w wypowiedziach publicystycznych (Klimek, 2011), jak i wystąpieniach oraz opracowaniach naukowych (Skowera, 2012). Od czasów pierwszej części animowanego cyklu o przygodach Shreka (Adamson, Jenson, 2001), która jeśli nie zainicjowała, to z pewnością dobitnie unaoczniła popkulturową ekspansję baśni, daje się zaobserwować ich coraz wyraźniejszą i coraz częstszą obecność już nie tylko w literaturze, lecz także w komiksie, kinie aktorskim, filmach animowanych, serialach, programach telewizyjnych, grach wideo, sztuce plakatu i fotografii, reklamie itd. (Ćwiklak, 2014; Kostecka, 2014; Kowalczyk, 2016; Mazela, 2013; Skowera, 2014; Stefaniak-Maślanka, 2015). Wzmożona popularność baśniowych opowieści wśród twórców i odbiorców nie jest, oczywiście, nowym zjawiskiem w historii kultury. W dziejach baśni nowożytnej trzeba by wskazać przede wszystkim na twórczość bywalczyń i bywalców francuskich salonów arystokratycznych XVII i XVIII wieku (Waksmund, 1998) i niemieckich romantyków (Waksmund, 2000, s. 193-201), a także modernistów i - z rodzimej 
perspektywy - młodopolan (Czabanowska-Wróbel, 1996; Leszczyński, 1990), wreszcie - autorek związanych z drugą falą feminizmu oraz tych zainspirowanych jej diagnozami oraz postulatami (Schanoes, 2014; Zipes, 1986). Jednakże, jak słusznie zwróciła uwagę Kamila Kowalczyk (2015), to „baśniowe renarracje przeżywają obecnie renesans” (s. 35), a więc „teksty kultury, które bazują przede wszystkim na zakorzenionym w masowej wyobraźni (treściowym i gatunkowym) wzorcu baśniowym, przekształcając wszystkie cechy formy tradycyjnej, proponując finalnie odbiorcy nową, w sposób twórczy przekształconą jej wersję" (Kowalczyk, 2016, s. 6).

Tak rozumiane przeobrażenia baśni ze szczególną uwagą i częstotliwością badano od lat 90. ubiegłego wieku, a kolejne opracowania naukowe wciąż powstają. Badacze i badaczki koncentrują się na intertekstualnych, metafikcyjnych i transfikcjonalnych grach $\mathrm{z}$ tradycją baśniową, a także transformacjach konstruktów kulturowych, schematów myślenia i konserwatywnych ideologii utrwalonych przez klasykę baśniową. Za szczególnie istotne prace - dostarczające nowych konceptów teoretycznych, tropów interpretacyjnych i diagnoz społeczno-kulturowych - w anglosaskim piśmiennictwie fachowym należy uznać monografie Cristiny Bacchilegi $(1997,2013)$, Martina Halletta i Barbary Karasek (2014), Vanessy Joosen (2011), Jessiki Tiffin (2009) czy też Jacka Zipesa (2006), a także najnowszą pracę Pauline Greenhill (2020). Ponadto opublikowano liczne tomy zbiorowe poświęcone tej tematyce, wśród których na szczególną uwagę zasługują te pod redakcją naukową Greenhill, Jill Terry Rudy, Naomi Hamer i Lauren Bosc (2018), Greenhill i Rudy (2014), Christine A. Jones i Jennifer Schacker (2013), Anny Kérchy (2011), Stijna Praeta i Kérchy (2019) oraz Kay Turner i Greenhill (2012). W Polsce na temat kulturowych metamorfoz baśni pisały m.in. Kowalczyk (2016) i Violetta Wróblewska $(2003,2014)$ oraz autorka niniejszego artykułu (Kostecka, 2014).

W nurcie badań nad formami obecności baśni w kulturze sytuuje się interesująca monografia Magdaleny Bednarek (2020). Już sam tytuł pracy wskazuje na włączenie jej w obszar dociekań nad konstytutywną - zwłaszcza z dzisiejszego punktu widzenia - cechą baśni, a mianowicie ich nieustającymi kulturowymi metamorfozami. Baśni przeobrażone. Transformacje bajki i baśni w polskiej epice po 1989 roku to jednak książka wykraczająca poza paradygmat badawczy dotychczas najczęściej stosowany w Polsce. Autorka nie tylko prezentuje strategie opowiadania na nowo baśniowej klasyki przez rodzimych pisarzy i pisarki, lecz przede wszystkim ukazuje potencjał baśni polegający na przenikaniu rozmaitych jej elementów do różnorodnych wymiarów utworu literackiego i specyficznym organizowaniu jego struktury oraz na konstruowaniu fabuł, sensów i postaci w „twórczości niebaśniowej” (s. 17), niekoniecznie 
funkcjonującej w kulturowym mainstreamie. Jest to pierwsza polska monografia poświęcona tej problematyce; dotychczasowe publikacje miały charakter jedynie cząstkowych rozpoznań ${ }^{1}$. Jeszcze w XX wieku Ryszard Waksmund (1978) pisał wprawdzie w szkicu na temat, jak to ujmował, bajkosfery o „użyciu semiotycznym fabuł baśniowych" (s. 99), Jolanta Ługowska $(1981,1988)$ opublikowała zaś dwie prace fundamentalne dla rodzimych studiów nad formami obecności bajek ludowych i baśni artystycznych w kulturze literackiej. Opracowania te dotyczyły jednak przede wszystkim twórczości dla dzieci - baśniowej i fantastycznej - i sposobów wykorzystywania w niej „repozytorium [baśniowego] świata przedstawionego ([na które składają się] postaci, ich atrybuty, elementy scenografii)" (Bednarek, 2020, s. 17). Autorka Baśni przeobrażonych poszła o krok dalej i zaproponowała czytelniczkom i czytelnikom zbiór pogłębionych, autorskich analiz polskich utworów literackich z trzech ostatnich dekad - opowiadań i powieści utrzymanych głównie w konwencji realistycznej i adresowanych przede wszystkim do odbiorców dorosłych; tekstów, w których tkankę na rozmaite sposoby wniknęły bajka i baśń ${ }^{2}$ (o rozwiązaniach terminologicznych przyjętych przez Bednarek mowa będzie nieco dalej). Jak wyjaśnia we wstępie sama badaczka, jej „książka zaczyna się więc w miejscu, w którym Waksmund i Ługowska zamknęli swoje dociekania [...]" (s. 17). Bednarek była zresztą doskonale przygotowana merytorycznie do takiego przedsięwzięcia badawczego - w minionej dekadzie opublikowała kilka artykułów poświęconych inspiracjom baśniowymi fabułami i konwencjami przejawiającym się we współczesnej polskiej prozie (m.in. Bednarek, 2011, 2016a, 2017a, 2018), a także w utworach zagranicznych (Bednarek, 2016b). Jest również autorką ważnego (i niestety chyba wciąż za mało znanego w środowisku akademickim) artykułu krytycznego na temat słynnej monografii Brunona Bettelheima (1975/1985) i jej polskiej recepcji (Bednarek, 2017b).

Magdalena Bednarek (2020) stawia słuszną tezę - zgodną z ustaleniami wszystkich wymienionych wcześniej badaczy oprócz Bettelheima - iż „przeobrażenie to jedna z [...] charakterystycznych cech" baśni (s. 11), która, paradoksalnie, gwarantuje ich trwałość. Nie tyle przechowywanie ponadczasowych znaczeń i przesłań, ile właśnie zdolność do przekształcania się wraz z realiami,

1 Zob. np. teksty zebrane w tomie pod redakcją naukową Kornelii Ćwiklak (2014), w części zatytułowanej „Baśń w polskiej literaturze współczesnej”.

2 Warto dodać, że również w anglosaskiej literaturze przedmiotu odnaleźć można stosunkowo niewiele publikacji poświęconych formom obecności elementów baśni w epice niebaśniowej. Jednym z częściej cytowanych wyjątków jest monografia Ann Martin (2006) dotycząca modernistycznej twórczości Jamesa Joyce’a, Virginii Woolf oraz Djuny Barnes. 
w których baśniowe opowieści są (re)konstruowane - wchłaniania i transmitowania określonych wartości, wzorców i ideologii - stanowi bowiem ich konstytutywną własność. Czyniąc takie założenie, autorka nawiązuje niejako do historyczno-socjologicznej szkoły badań nad baśniami, reprezentowanej przez takich badaczy, jak wspomniany już Zipes czy też Ruth Bottigheimer i Maria Tatar, w Polsce zaś m.in. Waksmund, Ługowska i Kowalczyk (w przypisie bibliograficznym oraz bibliografii recenzowanej monografii niestety błędnie nazywana Kowalską). W ostatnich dekadach owa tendencja do metamorfoz przybrała na sile; diagnozę, zgodnie z którą dzisiejsze „baśni przeobrażone” zasadzają się w dużej mierze na pogłębionej reinterpretacji swoich klasycznych wariantów (s. 12), należy więc uznać za trafną.

Owe rozmaicie przeprowadzone przez pisarzy i pisarki reinterpretacje znalazły się w centrum zainteresowania Bednarek, która w rodzimych utworach prozatorskich wydanych po 1989 roku poszukuje, po pierwsze, gatunkowych metamorfoz baśni, po drugie, przekształceń popularnych wątków i motywów, po trzecie zaś - przeobrażań postaci (przede wszystkim bohaterek). Zakorzenioną w polskim literaturoznawstwie cezurę roku '89 - „otwierając[ego] nową Polskę, stwarzającą szansę na nową literaturę" (Kulesza, 2013, s. 56) słusznie uzasadnia zmianą kontekstu estetycznego, historycznoliterackiego, społecznego, ideologicznego oraz pragmatycznego, oddziałującego także na kierunek przeobrażeń baśni (Bednarek, 2020, s. 18). Istotnie, o ile w latach 90. rodzimy rynek książki dziecięcej został zalany publikacjami jednoznacznie dziś określanymi jako tandetne tak pod względem treściowym, jak i edytorskim (Olech, 2008), o tyle baśń przejawiająca się w twórczości dla odbiorców dorosłych miała się coraz lepiej. To wtedy swoje rewolucyjne Bajki - społeczno-polityczne manifesty - opublikowała Matka Bolka (1993; pod tym pseudonimem kryła się Beata Kozak), wtedy też pojawiły się przekłady takich dzieł, jak Królewna Śnieżka Donalda Barthelmego (1965/1999) czy Turbot Güntera Grassa (1977/1995). U progu nowego millenium polscy czytelnicy mogli zaś wreszcie zapoznać się z opowiadaniami Angeli Carter (2000) - na Zachodzie wówczas już mającymi status kultowych - zebranymi w tomie Czarna Wenus, oryginalnie opublikowanymi m.in. w słynnym tomie The Bloody Chamber ponad dwadzieścia lat wcześniej (Carter, 1978). Ponadto Bednarek wskazuje na mnożące się po roku 1989, poświęcone baśniom interdyscyplinarne konferencje i monografie naukowe, skutkujące popularyzacją nieznanych dotąd w Polsce koncepcji teoretycznych i tekstów kultury, a także na wzrost zainteresowania baśniami wśród obiorców nieprofesjonalnych. $Z$ tej perspektywy baśniowe bogactwo form i treści w twórczości polskich prozaików i prozaiczek ostatnich trzydziestu lat wręcz domagało się próby całościowego opisu i starannego 
usystematyzowania. Baśni przeobrażone to więc monografia nie tylko bardzo interesująca, lecz także wyraźnie potrzebna.

Autorka podkreśla niejednokrotnie, że przedmiotem jej dociekań jest literatura mająca dorosły adres czytelniczy. Mimo to włącza do rozważań utwory skierowane do czytelników dziecięcych. Usprawiedliwieniem takiej strategii jest poniekąd pozostawienie sobie przez badaczkę otwartej furtki w postaci wzmianki o możliwej dwuadresowości utworów: „[monografia] eksploruje przede wszystkim literaturę adresowaną do dorosłego odbiorcy (lub także do dorosłego odbiorcy) [...]" (Bednarek, 2020, s. 17). Pewną konsternację może jednak wzbudzić obecność w książce autonomicznych i obszernych studiów przypadków takich, jak Krulewna [!] Śnieżka Bohdana Butenki (2008), Wroniec Jacka Dukaja (2009) i Co się stało z naszq̨ bajką? Hanny Krall (1994), następujących po deklaracji: „Literaturę adresowaną do młodszego odbiorcy, stricte baśniową, bajki magiczne oraz nieliterackie teksty kultury przywołuję jako konteksty interpretacyjne" (Bednarek, 2020, s. 17-18). Tym bardziej że wymienione utwory doczekały się już przecież opracowań naukowych (spośród których część została przywołana przez badaczkę), także w interesującym Bednarek kontekście (m.in. Kostecka, 2014, 2018; Kowalczyk, 2016; Rusek, 2015). Jako że przywołane teksty literackie stanowią wyjątki w obszernym materiale badawczym zawierającym „wykraczającą poza konwencję baśni” literaturę dla odbiorców dorosłych (Bednarek, 2020, s. 17), jednoznaczne i klarowne umotywowanie takiego, a nie innego wyboru utworów z pewnością rozwiałoby potencjalne wątpliwości czytelników. Dlaczego Wroniec, a nie pominięta w analizie opowieść Jak zostałam wiedźma Doroty Masłowskiej (2014), skoro w obu tych utworach ,jednostkowy, egzystencjalny wymiar istnienia, tak ważny w baśni, dzięki odniesieniom do współczesności określają [...] także cechy życia zbiorowego" (Rusek, 2015, s. 312-313)? Dlaczego tylko Krulewna [!] Śnieżka, ale już nie Pyś, czyli wiadukt nad chaszczami także autorstwa Butenki (1998), podobnie jak ta pierwsza opierający się na chwycie dekonstrukcji? Wreszcie - dlaczego Co się stało z naszą bajką?, nie zaś w zbliżony sposób autotematyczne: nieanalizowana w monografii Jedna noc czarownicy Doroty Terakowskiej (2003) lub przywołany jedynie kontekstowo Kopciuszek idzie na wojne, czyli historia kołem się toczy Sławomira Shutego (2012)? Bednarek sugeruje wprawdzie unikatowość gier z baśniową tradycją w tomie Butenki, powieści Dukaja i opowiadaniu Krall, wyjątkowość ta nie wydaje się jednak niepodważalna.

Niemniej, bez względu na motywację stojącą za wyborem poszczególnych utworów należy docenić bardzo rzadkie wśród rodzimych literaturoznawców podejście polegające na łącznym rozpatrywaniu literatury dla młodych czytelników i bezprzymiotnikowej oraz włączanie tej pierwszej w obszar 
humanistycznych badań nad przeobrażeniami kultury literackiej sensu largo. Tak więc Wroniec znajduje się tutaj w tym samym polu badawczym co adresowane do dorosłych utwory Bohdana Sławińskiego i Ignacego Karpowicza, analizy baśniowych opowiadań Butenki i Krall sąsiadują z rozważaniami nad twórczością Olgi Tokarczuk, Izabeli Filipiak czy Mariusza Sieniewicza, a wzmianki o mających dziecięcy adres czytelniczy tekstach Elizy Piotrowskiej, Michała Rusinka czy Grzegorza Kasdepkego dopełniają dociekania dotyczące powieści Anny Nasiłowskiej, Krystyny Kofty, Bereniki Miszczuk itd. Można wręcz żałować, że autorka nie pokusiła się o uwzględnienie w materiale badawczym chociaż kilku polskich powieści młodzieżowych (choć oczywiście odniesienie się do choćby części tego segmentu rodzimego rynku książki mogłoby skutkować zbyt daleko idącym zwiększeniem rozmiarów recenzowanej monografii). Ważnym i nowatorskim posunięciem z perspektywy „przyzwyczajeń” rodzimego literaturoznawstwa jest też nierozdzielanie kultury wysokoartystycznej i popularnej. Granice między tymi dwoma kulturowymi rejestrami wydają się dzisiaj coraz bardziej rozmyte i trudno uchwytne, a niejednokrotnie wręcz ustanawiane sztucznie; Bednarek udowadnia, że baśń - od stuleci zresztą funkcjonująca w rozmaitych obiegach - nie uznaje tego typu „linii demarkacyjnych” i przenika do najrozmaitszych tekstów. „Baśni przeobrażone” analizowane przez badaczkę to zatem utwory nie tylko takich autorów i autorek, jak wspomniani już Sławiński, Karpowicz, Tokarczuk czy Sylwia Chutnik, lecz także Katarzyna Grochola, Małgorzata Kalicińska oraz Małgorzata Szwaja. Bednarek bez wątpienia dostrzega i rozumie specyfikę poszczególnych utworów, ale ich nie wartościuje pod względem przynależności do określonego rejestru kultury. Zarówno studia przypadków zasadzające się na close reading, jak $\mathrm{i}$ analizy o charakterze przekrojowym zostały przez nią przygotowane $\mathrm{z}$ wyczuwalną pasją badawczą i założeniem, że określony w tytule pracy przedmiot badań stanowi złożoną, niejednorodną, intertekstualną "baśniową sieć” [ fairy-tale web], jak ujęłaby to Bacchilega (2013, s. 1-30).

Zastanawiające są rozwiązania terminologiczne przyjęte przez Bednarek (2020) i sposób stosowania wybranych pojęć. Autorka zwraca uwagę na „dyskusyjną separację bajki i baśni” w polskim dyskursie naukowym. Oczywiście, słusznie argumentuje, że "twórcy wykorzystują w tych samych tekstach elementy przynależące do obu gatunków”, i przypuszczalnie ma na myśli - generalnie rzecz ujmując - tak folklor, jak i zróżnicowane źródła literackie. Nie podaje jednak przykładów takiej „dyskusyjnej separacji”, wskazując jedynie, że w środowisku akademickim mamy z nią do czynienia „co najmniej od pięćdziesięciu lat” (s. 11). Warto jednak przypomnieć, że takie zjawisko nie występuje chociażby w ostatniej monografii Wróblewskiej (2014). Sugerowany przez Bednarek chaos 
pojęciowy ${ }^{3}$ miałby wynikać z mnogości terminów o nieprecyzyjnym znaczeniu i niekonsekwentnie stosowanych. To, z jednej strony, częściowo trafna obserwacja, ale $\mathrm{z}$ drugiej - nie można zapominać o fundamentalnych ustaleniach badawczych funkcjonujących w literaturze fachowej po dziś dzień, dostarczających solidnych i klarownych ram pojęciowych ${ }^{4}$. Ogromny wysiłek definicyjny podjął bez wątpienia Julian Krzyżanowski (1965), objaśniając m.in. pojęcia bajki ludowej i bajki magicznej. Ługowska (1981, s. 31-32) rozróżniła baśń ludową i literacką na podstawie kryterium formy przekazu - oralnego i poprzez zapis. Waksmund (2000, s. 186-187) wskazał na konieczność wyodrębnienia dwóch odmian baśni literackiej ze względu na jej dwa źródła - folklor i oryginalny pomysł autora. Wróblewska (2003, s. 20) skorzystała zaś z ustaleń wszystkich wymienionych badaczy: zastosowała kryterium związków tekstu z folklorem, wyodrębniając baśń ludową i literacką, w ramach tej drugiej wydzieliła zaś literacką baśń tradycyjną (mającą charakter adaptacji) oraz literacką baśń nowoczesną (opartą na autorskim pomyśle); typologia ta bywa wykorzystywana do dzisiaj. Bednarek (2020) wprawdzie wskazuje na problem metodologiczny polegający na tym, że „»bajka“ należy naraz do dwóch dziedzin humanistyki (folklorystyki i literaturoznawstwa) i w obrębie każdej z nich oznacza odmienne pojęcia, a także wchodzi w relacje z innymi terminami”, i dodaje, że inaczej niż folklorysta, „literaturoznawca [...] rozróżnia bajkę (ezopową) i baśń" (s. 26), ale przecież zarówno Ługowska jako filolożka polska specjalizująca się w folklorystyce, jak i Wróblewska będąca zarazem literaturoznawczynią i folklorystką udowodniły, że obie te dziedziny mają wiele punktów wspólnych.

Według Bednarek (2020) mamy jednak do czynienia z „terminologicznym zamętem”, który pogłębiany jest przez „uzus, bajką potocznie nazywa się bowiem utwory dla dzieci w ogóle - bez względu na ukształtowanie świata przedstawionego, narracji, języka czy nawet medium" (s. 11). W tym wypadku wypada zgodzić się z diagnozą autorki; kuszące byłoby założenie, że to problem poniekąd sztuczny, gdyż niedotyczący dyskursu naukowego - potoczne używanie pojęcia bajki przenika jednak nawet do języka krytyków i krytyczek literackich mających duże doświadczenie (Dunin, 2020). Wobec tego propozycja Bednarek (2020) jest następująca:

3 Dylematy terminologiczne w tym zakresie nie są zresztą polską specyfiką; w piśmiennictwie anglosaskim dyskutuje się nad takimi pojęciami, jak fairy tale oraz używanymi z nim wymiennie (i pytanie, czy słusznie) magic tale i wonder tale (Haase, 2016, s. 322).

4 Ich syntetyczne omówienie można znaleźć w rozbudowanym haśle problemowym autorstwa Wróblewskiej (2016-2018) w słowniku poświęconym polskiej bajce ludowej pod redakcją naukową tej samej badaczki. 
Termin bajka (jednoczłonowy) traktuję sensu largo jako określenie dla rodziny gatunków, w skład której wchodzą najróżniejsze bajki: ludowa, zwierzęca, magiczna, ezopowa, „bajeczka” itd., a także baśń literacka czy literackie adaptacje wątków folklorystycznych. Uważam, że takie podejście pozwala lepiej ująć współczesną, niejednorodną, przepełnioną intertekstualnością specyfikę zjawiska niż klarowne teoretyczne klasyfikacje (s. 12).

Jest to, trzeba przyznać, rozstrzygnięcie dość odważne, zważywszy na uzus badawczy w polskim literaturoznawstwie, w którym takie zastosowanie terminu „bajka”, mimo analogicznej propozycji Ługowskiej (1988) sprzed trzech dekad, nie zyskało popularności ${ }^{5}$. Niemniej, ze względu na wielowymiarową intertekstualność powieści i opowiadań analizowanych w recenzowanej monografii nadrzędna kategoria terminologiczna rzeczywiście wydaje się przydatna i śmiałe sięgnięcie po tę „brzytwę Ockhama” może być wręcz uznane za godne podziwu. Niepokojąca jest jednak niekonsekwencja w zastosowaniu tej kategorii. Skoro „bajka” ma być terminem nadrzędnym, dlaczego autorka zdecydowała się na określenie „baśni przeobrażone” w tytule swojej monografii, w podtytule zaś rozdzieliła „bajki” i „baśni”? " Dlaczego tu i ówdzie traktuje te pojęcia synonimicznie („najbliżsi ujęcia specyfiki baśni byli Jolles i [...] Lüthi, którzy, wychodząc od analizy stylu, narracji i kompozycji bajki, doszli do opisu świata w niej przedstawionego"; Bednarek, 2020, s. 81), gdzie indziej zaś - jako dwa odrębne terminy („Pisarze, którzy sięgają po bajki i baśnie, nie zawsze jednak traktują je jak repertuar wątków, które prowokują do odświeżenia lub nawet domagają się go swoją anachronicznością"; s. 105)? Wszystko to sprawia, że gdy autorka pisze o „bajkowości i baśniowości” (np. s. 25), czytelnik nie ma pewności, co dokładnie ma ona na myśli. Bardziej konsekwentne stosowanie terminu „bajka” w miejsce „baśni” byłoby też wskazane we fragmentach (s. 27) odsyłających do ustaleń Władimira Proppa (1928/1976), którego przedmiotem badań była ludowa bajka magiczna. Z kolei kategoryzowanie jako „baśni” Alicji w Krainie Czarów Lewisa Carrolla (1865) i stawianie jej w jednym rzędzie z opowieściami o Śpiącej Królewnie, Śnieżce, Kopciuszku i Czerwonym

5 Dyskusyjne jest także rozdzielenie baśni literackiej i „literackich adaptacji wątków folklorystycznych" w zacytowanej definicji.

6 Co ciekawe, w angielskim streszczeniu książki umieszczonym na jej końcu Bednarek (2020) przekłada podtytuł monografii jako The Metamorphosis of Fairy Tales in Polish Literature after 1989. Słownikowe znaczenie terminu fairy tale faktycznie obejmuje nie tylko „baśń”, lecz także „bajkę”, jednakże w anglosaskiej literaturze fachowej używa się pojęcia fairy tale w ściśle określonym znaczeniu, które nie może być utożsamione z „bajką” rozumianą tak, jak proponuje to Bednarek. 
Kapturku (Bednarek, 2020, s. 94-95) wymagałoby wyjaśnienia. W zakończeniu monografii powraca jednak koncepcja „bajki” jako kategorii nadrzędnej:

Jak dowodzą powieści Sławińskiego, Dukaja oraz Karpowicza, forma ta rozumiana jest elastycznie i szeroko; obejmuje całą rodzinę gatunków określaną zbiorczo nazwą bajki: a więc baśń literacką z jej poetyzmami, bajkę magiczną cechującą się abstrakcyjnym stylem oraz schematyzmem fabularnym, bajkę dla dzieci ze skłonnością do upraszczania i łagodzenia oraz bajkę zwierzęcą z tendencją do moralizowania i paraboliczności (s. 267-268).

O ile więc w niektórych fragmentach Baśni przeobrażonych teoretyczny zamysł autorki wydaje się nie w pełni jasny, o tyle ponownie klarowny staje się w podsumowaniu.

Trzy zasadnicze rozdziały recenzowanej monografii odpowiadają przyjętym przez Bednarek perspektywom badania form obecności baśni w epice niebaśniowej. Rozdział pierwszy, zatytułowany Skradziony język baśni, poświęcony jest przeobrażeniom baśni jako gatunku. Swoje fundamentalne dla tej części monografii założenie autorka formułuje następująco:

Bajkowość i baśniowość traktuję [...] jako konwencję literacką, którą można podejmować punktowo i fragmentarycznie, nie dążąc bynajmniej do stworzenia bajki ani baśni. W najnowszej prozie jest ona wykorzystywana w celu nawiązywania do bajkowej i baśniowej aksjologii oraz symboliki, z którą tekst wchodzi w dialog (Bednarek, 2020, s. 24).

Bednarek prezentuje trzy interesujące studia przypadków: Wrońca Dukaja, Królowej Tiramisu Sławińskiego (2008) oraz Sońki Karpowicza (2014). Pierwszą z wymienionych powieści określa jako „baśń synkretyczną” (Bednarek, 2020, s. 25), jako że Dukaj sięgnął, w jej interpretacji, do tradycji „bajki dziecięcej, zwierzęcej, magicznej” (s. 76). Drugą - jako „baśń nieświadomą” (s. 48); badaczka pokazuje, w jaki sposób baśniowa opowieść, która początkowo wydaje się autonomiczną (w sensie kompozycyjnym i graficznym) całostką, stopniowo przejmuje cały utwór, kształtując jego najważniejszy, psychologiczny wątek, oraz stanowi klucz interpretacyjny jako „symboliczna transfiguracja planu realistycznego" (s. 48). Wreszcie, w trzeciej powieści Bednarek tropi aluzje do bajki magicznej - w postaci m.in. drobnych elementów jej świata przedstawionego - oraz wskazuje na ich wymiar metatekstowy. Rozważania te prowadzą autorkę do wniosku, że „baśń, pozbawiona swojego semantycznego wymiaru, okazuje się pustą formą, którą można reprodukować w całości lub we fragmentach jako artefakt" (s. 85). 
W końcowej części tego rozdziału Bednarek (2020) proponuje interesującą definicję antybaśni. Stwierdza mianowicie, po pierwsze, że analizowane powieści, będąc antybaśniami, obnażają poprzez zastosowane konwencje narracyjne „nieadekwatnoś[ć] baśni jako konwencji estetycznej i sposobu poznania wobec opowiadanej rzeczywistości" (s. 84); po drugie zaś - że antybaśń zachowuje poznawcze i estetyczne wartości baśni, natomiast neguje jej wymiar kompensacyjny („pocieszycielski”; s. 85). To z kolei prowadzi badaczkę do wniosku, że antybaśń może „zdradzać na równi świadomość niemożności baśni, jak i tęsknotę za nią oraz oferowanymi przez nią gratyfikacjami: poczuciem bezpieczeństwa, a dalej przekonaniem o istnieniu sprawiedliwości, sensu i ładu w rzeczywistości” (s. 86). Ostatecznie autorka decyduje się „szersze pojęcie antybaśni zarezerwować dla [...] zjawisk architekstualnych, natomiast o tekstach o charakterze intertekstualnym mówić za pomocą takich pojęć, jak trawestacja, reinterpretacja, parodia, pastisz, prze-pisywanie czy retelling" (s. 87). Takie rozstrzygnięcie metodologiczne jest uzasadnione; $w$ istocie, większość badanych przez nią retellingów można uznać za antybaśnie w powyższym rozumieniu (jak np. Co się stało z naszą bajką? Krall), podczas gdy nie każda antybaśń jest retellingiem (np. powieści Dukaja, Sławińskiego i Karpowicza).

Właśnie o retellingach baśni traktuje rozdział drugi pt. Prze-pisywanie fabuł. Jako najbardziej złożony pod względem poruszonych zagadnień, materiału badawczego i metodologii, zostanie tutaj omówiony najobszerniej ze wszystkich trzech części. Bednarek (2020) przedstawia w nim autorską koncepcję, zgodnie z którą „o ile retelling ma wymiar głównie estetyczny, w prze-pisywaniu [...] priorytetem jest cel polityczny" (s. 89), co jest rozstrzygnięciem tyleż inspirującym, co arbitralnym. Ostatecznie natomiast - zanegowawszy koncepcję Macieja Skowery (2016) dotyczącą różnic między retellingiem a rewritingiem - stwierdza: „Prze-pisywanie uznaję [...] za intertekstualną praktykę polegającą na takim opowiedzeniu znanej fabuły, by stanowiła ona reinterpretację pre-tekstu. Retelling jest dla niego synonimem i nie ogranicza się do baśni” (s. 168). Autorka przekonuje, że literaturoznawcy anglosascy uznają retelling i rewriting (jak również renarration ${ }^{7}$ ) za synonimy, i na dowód przywołuje m.in. prace Bacchilegi (1997) oraz Christiana Moraru (2001). Wypada jednak zauważyć, że w swojej kolejnej monografii Bacchilega (2013, s. 35) nie utożsamia już tych dwóch pojęć, lecz uznaje retelling za jedną z kilku możliwych form rewritingu; nie mówiąc już o tym, że Moraru (2001) przecież jednoznacznie uzależnia utożsamianie obu terminów od kontekstu użycia: „,retelling

W Polsce pojęcie renarracji wprowadziła do badań nad baśniami Kowalczyk (2016). 
i rewriting nie są synonimami. Kiedykolwiek używam terminu retelling jako ekwiwalentu rewritingu, mam na myśli precyzyjny, szczegółowy, przemyślany i oparty na ideologii retelling napisanych wcześniej narracji” (s. 180) ${ }^{8}$.

Mimo początkowej deklaracji, że fantasy nie stanowi przedmiotu jej badań, ponieważ „choć wykorzystuje elementy baśni, przekształca je systemowo, tworząc własną konwencję gatunkową"' (Bednarek, 2020, s. 17), autorka analizuje w swojej monografii baśniowe retellingi Andrzeja Sapkowskiego. Uzasadnia to tym, że dzięki jego twórczości „opowiadanie baśni na nowo stało się istotną częścią polskiego krajobrazu literackiego [...]” (s. 91). Istniejące już analizy dotyczące intertekstualności utworów Sapkowskiego wzbogaca uwagami na temat współtworzenia przez przeobrażone baśnie wiedźmińskiego uniwersum - m.in. kreacji protagonisty, obrazu społeczeństwa oraz dziedzictwa kulturowego. W tym rozdziale szczegółowo analizuje również tekst i ilustracje w tomie Krulewna [!] Śnieżka Butenki, słusznie wskazując na ważne zjawisko rekanonizacji baśni (o którym, używając pojęcia „procesu kanonizacji”, swego czasu pisała Joosen; 2011, s. 17). Z kolei w odniesieniu do utworu Co się stało $z$ nasza bajką? prowadzi interesujące rozważania na temat jego potencjalnej transfikcjonalności, nawiązując do koncepcji Richarda Saint-Gelaisa (2011). Jak konkluduje: „[...] gra z literackim punktem odniesienia jest nie tylko widoczna, ale wręcz manifestacyjna. Opowiadanie Krall byłoby więc przypadkiem granicznym: transfikcjonalność nie ma w nim funkcji światotwórczej, a służy refleksji metaliterackiej” (Bednarek, 2020, s. 108).

W dalszej części rozdziału autorka poddaje ciekawej refleksji próby łączenia elementów baśni z prezentacją realnej czasoprzestrzeni w utworach Tokarczuk (1996) oraz Andrzeja Pilipiuka (2002) i przekonuje, że „konkretyzacja chronotopu nie prowadzi do większego realizmu ani zlikwidowania uniwersalności czy ponadczasowości opowieści” (Bednarek, 2020, s. 118) ${ }^{10}$. Ponadto, analizuje strategie opowiadania klasycznych baśni na nowo współczesnym językiem (m.in. książka Bartosza Sztybora, Piotra Nowackiego oraz Łukasza Mazura, 2016), wykorzystywania baśniowego schematu fabularnego i rekwizytorium do przedstawienia nowej, oryginalnej historii (powieść hipertekstowa Marty Dzido, b.d.), czy też czerpania z baśni w literacko-publicystycznych obserwacjach społecznych i politycznych (m.in. opowiadania Daniela Passenta,

8 Jeśli nie podano inaczej, wszystkie tłumaczenia autorki artykułu - Weroniki Kosteckiej.

9 Autorka zwraca także uwagę, że strategie nawiązywania do baśni w fantasy były już w Polsce wielokrotnie badane.

10 Dla porównania warto zapoznać się z odmienną interpretacją opowiadania Pilipiuka zaproponowaną przez Kowalczyk (2016, s. 169-173). 
1994). Frapujące okazują się także rozważania Bednarek (2020) na temat, jak to określa, „defamiliaryzacji baśni” (s. 129); przedmiotem analizy jest tutaj powieść Sieniewicza (2010). Jak dowodzi autorka: „Znajomy kontekst pozwala dostrzec w historii Jasia i Małgosi niepokojącą dziwność, a także każe na nowo [...] spojrzeć na otaczającą nas rzeczywistość społeczno-kulturową" (Bednarek, 2020, s. 129).

„Baśni (nie)poprawne politycznie” to szczególnie interesująca część tego rozdziału. Autorka konstatuje, że choć pojęcie poprawności politycznej wciąż wydaje się w Polsce nierozumiane, feminizm zadomowił się w rodzimym dyskursie społecznym i politycznym, a także w rodzimej literaturze. Odwołując się m.in. do niepokornych Bajek Matki Bolka i Madame Sinobrodej Renaty Bożek (2005), Bednarek (2020) zauważa, że „polska proza najnowsza zdecydowanie bardziej [...] akcentuje krytyczny niż mitotwórczy aspekt prze-pisywania” baśni, mając na myśli „dwa cele wyznaczające continuum feministycznego baśniopisarstwa: roztrzaskiwanie patriarchalnych mitów oraz tworzenie nowych, kobiecych" (s. 151). Istotnie, polscy autorzy i autorki zdecydowanie chętniej stawiają krytyczną diagnozę rzeczywistości społecznej, tak jak czyniła to Carter, niż proponują literacką „receptę” poprzez promowanie idei wspólnoty kobiet i siostrzeństwa w duchu (nieznanych w Polsce) baśniowych retellingów Emmy Donnoghue (Kostecka, 2016).

Z kolei fragment tej części recenzowanej monografii dotyczący „queerowania baśni” (Bednarek, 2020, s. 152) okazuje się kontrowersyjny z powodu użytego przez autorkę aparatu pojęciowego. Turner i Greenhill (2012) we wstępie do tomu dotyczącego, jak głosi jego tytuł, „baśni transgresyjnych” i „queerowania Grimmów” oraz poświęconego poszukiwaniom „queerowych, lesbijskich, homoseksualnych, transpłciowych i transbiologicznych” szczegółów baśniowego świata przedstawionego (s. 3) wyjaśniały:

Zgodnie z dziewiętnastowiecznym użyciem tego terminu baśnie są queerowe w znaczeniu: dziwne, [...] ekscentryczne, inne, a jednak atrakcyjne. [...] Ale [baśniowy] gatunek i jego opowieści eksplorują również queerowość w znaczeniu nadanym mu przez XX- i XXI-wieczne jego rozumienie [...]; implikują egzystencje i teorie odnoszące się do płci i seksualności poza mainstreamem i odbiegające od normy [...] (s. 4).

Tymczasem Bednarek rozpoczyna swoje rozważania od przywołania zbioru baśni napisanego przez Agnieszkę Suchowierską (2012) we współpracy z Wojciechem Eichelbergerem, w którym autorzy zastosowali m.in. zabieg inwersji płci klasycznych baśniowych bohaterów i bohaterek - o czym informuje już 
sam tytuł tomu: Królewicz Śnieżek. Interpretując zawartą w nim opowieść o Czerwonym Kapturku, Bednarek (2020) pisze: „Jedna transseksualizacja pociąga za sobą kolejne, zmierzające do tego, by znana sekwencja wydarzeń opowiadała o kształtowaniu się męskiego podmiotu” (s. 153) ${ }^{11}$. Na „transseksualizację" postaci (s. 154) wskazuje również w odniesieniu do tomu Weroniki Jóźwiak (2015) opartego na analogicznym zabiegu. Nie sposób jednak przystać na taką interpretację; bohaterowie i bohaterki Suchowierskiej oraz Jóźwiak nie są przecież osobami transseksualnymi. Można się zastanawiać, czy przez „transseksualizację” autorka recenzowanej monografii nie rozumie po prostu gry z konstruktami genderowymi, co byłoby zresztą hasłem znacznie bardziej adekwatnym do analizowanej problematyki. Trudno także zgodzić się z konstatacją Bednarek (2020), że „Jóźwiak [...] udaje się [...] dokonać transseksualizacji bez ingerencji tak w fabułę, jak i aksjologię. Brak wpływu tej zmiany na przebieg i sens akcji każe jednak pytać o celowość tej adaptacji” (s. 154). Pomijając skądinąd arcyciekawe zagadnienie zasadności pytania o „celowość” jakiegokolwiek tekstu kultury, warto przypomnieć, że sfera aksjologii zostaje zdeterminowana właśnie przez literacką inwersję płci (nie „transseksualizację”!) wszystkich postaci w obu przywoływanych tutaj tomach. Autorka odwołuje się w przypisie, a więc na marginesie rozważań, do spostrzeżeń Malwiny Wajdy (b.d.) na temat przebudowy sposobu „myślenia o wzorcach męskości i kobiecości tak wśród młodych, jak i dorosłych czytelników” (Bednarek, 2020, s. 154) - ale przecież to jest właśnie kluczowe dla interpretacji tych utworów. W efekcie zewnątrztekstowej zmiany płci bohaterowie wydają się pasywni, infantylni, a w związku z tym - nudni, bohaterki zaś - aktywne, samodzielne i sprawcze. Ta prosta strategia inwersji ujawnia wiele społecznych skojarzeń związanych z tradycyjnymi rolami płciowymi. Sytuacje życiowe poszczególnych postaci mogą wydawać się dziwne, nietypowe, niektóre z nich - może nawet godne pożałowania. Jak pisze Grażyna Lasoń-Kochańska (2018) w - nieprzywołanej przez Bednarek - analizie tomu Suchowierskiej i Eichelbergera:

W baśni [o Kopciuszku] wymiana genderowa przynosi najbardziej widoczny efekt; wykorzystywany młody mężczyzna, który nikomu się nie sprzeciwia, nie

11 Abstrahując od kwestii merytorycznych, trzeba zauważyć, że termin "transseksualizacja” nie wydaje się dzisiaj pojęciem fortunnym, mimo że Bednarek (2020, s. 139) rozumie istotność poprawności politycznej. Być może owo kontrowersyjne pojęcie zaczerpnęła z prac Judith Butler, którą przywołuje w recenzowanej monografii. W omawianej tu części powołuje się na Uwikłanych w płeć (Butler, 1990/2008); terminy w polskim przekładzie oddane jako „transseksualizm”, „transseksualista” i „transseksualizacja” (ten ostatni w innym kontekście niż u Bednarek) pojawiły się w druku niemal trzydzieści lat temu (Butler 1993/2004). 
budzi współczucia, prędzej kpinę, a może nawet pogardę. Opowieść pokazuje, jak bardzo ciągle jesteśmy przywiązani do tradycyjnego podziału ról płciowych, skoro szydełkujący chłopiec jest dla naszej wyobraźni nie do przyjęcia (s. 68).

Można więc pokusić się o tezę, że gdy hipotetyczny czytelnik lub hipotetyczna czytelniczka zda sobie sprawę ze swojej „tradycyjnej” reakcji na „nietradycyjny" wzorzec płci, przypuszczalnie pojawi się refleksja nad rolami płciowymi przypisywanymi kobietom i mężczyznom (Kostecka, 2017, s. 217-218).

Do faktycznego „queerowania baśni” Bednarek zbliża się w swojej analizie Niebieskiej Kapturki Sztybora, Nowackiego i Mazur oraz powieści Tokarczuk Prowadź swój pług przez kości umarlych (2009), choć wciąż bardziej adekwatne byłyby tutaj uwagi na temat podważania normatywnych modeli genderowych. W odniesieniu do utworów dla najmłodszych czytelników Bednarek (2020) natomiast pisze, że „[...] najczęściej dotykają heteronormatywizmu. Poruszają jednak tę kwestię w zawoalowany sposób, korzystając z bajkowej symboliki o ugruntowanych znaczeniach" (s. 160). Niebezzasadna, choć też nieoczywista wydaje się konstatacja, iż książę występujący w Kopciuszku Rusinka (2006) - tu: syn bogatego biznesmana - „obojętny jest na wdzięk małych stópek, bo żadna część kobiecej fizjonomii go nie nęci” (Bednarek, 2020, s. 160). Taki wniosek autorka najwyraźniej wysnuwa na podstawie fragmentu opowieści mówiącego o znudzeniu bohatera balem („Ojciec kazał znaleźć pannę i ożenić się, niestety, no to siedział i udawał, że się patrzy na kobiety”, Rusinek, 2006, s. [19]) oraz enigmatycznej wzmianki o obojętności młodzieńca („Biznesmena syn poślubił pierwszą z brzegu (dosyć wredną), bo podobno co do kobiet to mu było wszystko jedno", s. [30-31]). Jeśli zinterpretować te ustępy jako świadczące o nieheteronormatywności bohatera, faktycznie trzeba uznać ten przekaz za bardzo zawoalowany - inaczej niż np. w przypadku bez wątpienia queerowej baśni Król i król Lindy de Haan (2000/2010). Oryginalną polską queerową opowieścią dla dzieci, nieuwzględnioną przez Bednarek $\mathrm{w}$ analizie, ale zgodnie z przyjętą przez nią metodologią mogącą chyba być nazwaną „bajką”, jest Kim jest ślimak Sam? Marii Pawłowskiej i Jakuba Szamałka (2015). Nieco inny dobór tekstów oraz przytoczenie jakichkolwiek koncepcji rozwiniętych na gruncie nowoczesnych queer studies (także tych zaproponowanych w badaniach nad baśniami) z pewnością wzbogaciłoby tę część monografii i uczyniło ją klarowniejszą.

Warto wspomnieć, że analizując baśniowe retellingi, Bednarek (2020, s. 168-169) zasadniczo odcina się od koncepcji wiążących je z postmodernizmem, dowodząc, że gry intertekstualne i motywy autotematyczne stosowane były przez twórców baśni już dużo wcześniej. Bez wątpienia ma rację, 
a zjawiska tego typu w szeroko pojętej literaturze baśniowej minionych stuleci zostały zresztą dość szeroko opisane (m.in. Kostecka, 2014, s. 123-159; Waksmund, 2005). Niemniej, intertekstualność i metafikcja stały się szczególnie widoczne $\mathrm{w}$ inspirowanych baśniami utworach doby postmodernizmu (Kérchy, 2011; Smith, 2007), przede wszystkim zaś przejawiają się w nich rozmaite napięcia ideologiczne prowadzące do prób dekonstruowania spetryfikowanych społecznych norm, co z postmodernizmem łączą m.in. Bacchilega (1997), Joosen (2011) i Kendra Reynolds (2020). Należy też dodać, że ani ja (Kostecka, 2014), ani Skowera (2016) nie definiowaliśmy i nie objaśnialiśmy „powieści postmodernistycznej” (Bednarek, 2020, s. 90), lecz właśnie baśń postmodernistyczną jako określenie właściwe dla zróżnicowanych gatunkowo tekstów. Anita Całek (2017, s. 50) zaś bynajmniej nie odrzuciła postmodernistycznych aspektów współczesnych retellingów baśni (Bednarek, 2020, s. 91). Sama autorka recenzowanej monografii odnajduje zresztą "postmodernistyczne aporie" w twórczości Sapkowskiego (s. 95).

Ostatni rozdział monografii, Metamorfozy postaci, Bednarek (2020) poświęca przeobrażeniom baśniowych bohaterek - przede wszystkim księżniczek i wiedźm. Zaczyna od interesującego spostrzeżenia, że kreowane na wzór baśniowej królewny protagonistki współczesnej polskiej prozy - doświadczające różnego typu patriarchalnej opresji: społecznej, seksualnej itd. - przedstawiane są często z wczesnofeministycznej, a więc bardzo krytycznej perspektywy. Księżniczka stanowi wówczas „negatywny wzorzec, który kobieta, dziewczyna musi przezwyciężyć, by ocaleć” (s. 192). Taki klucz interpretacyjny Bednarek stosuje w rozważaniach nad Siostra Małgorzaty Saramonowicz (1996), Matrioszką Dzido czy też Absolutna amnezją Filipiak (1995). W inspirujący sposób odczytuje również opowiadanie Królewna Śnieżka Nasiłowskiej (2002); dowodzi, że pełna wewnętrznych napięć i lęków bohaterka ucieka w głąb siebie niczym baśniowa protagonistka, która szuka schronienia w głębi lasu. W tej części rozważań autorka omawia też świetnie dobrane konteksty w postaci cykli fotograficznych grających z baśniową tradycją (zwłaszcza pod względem prezentowania bohaterek): Thomasa Czarneckiego (b.d.), Diny Goldstein (20072009) oraz Doroty Walentynowicz (2005). Bez wątpienia przedruk pojedynczych fotografii każdego $\mathrm{z}$ artystów wzbogaca analizę, pozwalając czytelnikom lepiej zrozumieć tropy interpretacyjne, którymi podąża Bednarek. Skądinąd wielka szkoda, że nie włączyła do rozważań fotografii Marii Dmitruk (2003) - polskiej artystki, która odwołując się do klasycznych baśniowych motywów, ukazała kobiecą starość i samotność; interpretacja tego cyklu przez Bednarek, specjalizującą się w feministycznych odczytaniach baśniowych tekstów kultury, z pewnością byłaby atrakcyjna. Ostatecznie badaczka dochodzi do wniosku: 
[...] postaci Śpiącej Królewny, Królewny Śnieżki, Roszpunki itd. funkcjonują tyleż jako postaci fikcyjne, co kompleksy oczywistych, powszechnie rozpoznawanych i ustabilizowanych (jednoznacznych) znaczeń, których nie trzeba eksplikować. [...] Baśniowa postać staje się nośnikiem nonkonformizmu i indywidualizmu, występując przeciw socjalizującej funkcji baśni, którą głosił Bettelheim (Bednarek, 2020, s. 206).

Równie zajmująco Bednarek (2020) pisze o współczesnych literackich reinterpretacjach postaci wiedźmy, inspirowanych, jak zauważa, drugą falą feminizmu, kiedy to czarownica została uznana za „uosobienie kobiety” (s. 211) wyzwolonej „od patriarchalnych stereotypów i wyrażającej własne pragnienie” (s. 212). Zróżnicowane strategie nawiązywania do tak rozumianego mitu wiedźmy przedstawia na przykładzie m.in. Prawieku i innych czasów Tokarczuk (1996), jak również powieści Grocholi (2001) czy też Szwai (2005). Poszukuje przy tym feministycznego wymiaru analizowanych utworów. W przypadku Tokarczuk czyni ciekawe spostrzeżenia dotyczące niegdysiejszego "przemilczania” tego aspektu jej twórczości oraz „feministycznej re-inkluzji” wspomnianej pisarki (Bednarek, 2020, s. 220). W odniesieniu do tekstów kultury popularnej wskazuje natomiast m.in. na podważającą ich feministyczne aspiracje reprodukcję „mitu [kobiecej] piękności” (s. 227). Nie dziwi zatem konkluzja, zgodnie z którą „emancypacyjny (względem dominującej patriarchalnej kultury) oraz transgresyjny (względem porządku estetycznego) charakter figury wiedźmy w ostatnim ćwierćwieczu stracił pazur" (s. 233). W tym kontekście autorka sygnalizuje jednak perspektywę rozwoju rodzimej prozy, a mianowicie rozkwitającą modę na mitologię słowiańską, w której mają swoje źródło intrygujące postaci znachorek i uzdrowicielek, jak np. w powieści Iwony Menzel (2014).

W zakończeniu monografii, rekapitulując swoje rozważania, Bednarek (2020) konkluduje, że bajka jako nadrzędna kategoria gatunkowa jest źródłem najrozmaitszych inspiracji dla polskich pisarzy i pisarek po 1989 roku - tak pod względem rozwiązań strukturalno-kompozycyjnych, zwykle reprodukowanych „bez zamysłów polemicznych” (s. 267), jak i repertuaru motywów, postaci i ideologii, które najczęściej zostają zakwestionowane i zrekonstruowane w nowych kontekstach. „Bajka odtwarzana jako forma [...] służy podtrzymaniu przekonania o spójności wspólnoty kulturowej i istotności konstytuujących ją wartości” (s. 268) - przekonuje autorka. Natomiast tradycyjne wątki „bywają postrzegane na kilka sposobów: jako repetycja, fantazja, repozytorium okropności, opresja oraz matryca poznawcza” (s. 268). Ponieważ klasyczne schematy fabularne i kryjące się za nimi kwestie ideologiczne niejednokrotnie okazują się opresyjne dla bohaterów i bohaterek, taki też mają wpływ - poprzez 
transmisję kulturową - na czytelników i czytelniczki, na co słusznie zwraca uwagę Bednarek, potwierdzając niejako słynną diagnozę Alison Lurie (1970) sprzed pięciu dekad i następczyń tej autorki. Współcześni pisarze i pisarki za pomocą rozmaitych intertekstualnych i architekstualnych strategii umożliwiają transgresję postaci literackich i wspierają dążenia emancypacyjne tych, którzy o niej czytają. „Prze-pisać bajkę to przejąć władzę, a przynajmniej rozbić jej monopol" (Bednarek, 2020, s. 269).

Baśni przeobrażone to bez wątpienia nowatorska monografia, dostarczająca wielu oryginalnych, inspirujących i intrygujących tropów interpretacyjnych w odniesieniu do zróżnicowanej polskiej prozy ostatnich trzydziestu lat. Książka otwiera przy tym przestrzeń do kolejnych eksploracji badawczych, prowokując wręcz do dalszych poszukiwań rozmaitych transformacji bajek $i$ baśni we współczesnej literaturze oraz form przejawiania się tradycji w nowych tekstach kultury. Magdalena Bednarek dowiodła, że baśnie są dla wszystkich i można je odnaleźć wszędzie: w najrozmaitszych kulturowych rejestrach i dziełach zróżnicowanych gatunkowo. Demokratyczny charakter ma też jej monografia: nie jest to hermetyczne opracowanie naukowe dostępne jedynie dla ekspertów, lecz zajmujące studium baśniowego pejzażu literackiego w Polsce i dowód na to, że wbrew protekcjonalnym diagnozom (Dunin, 2020) bajek nie czytamy wyłącznie w dzieciństwie.

\section{Bibliografia}

Bacchilega, C. (1997). Postmodern fairy tales: Gender and narrative strategies. University of Pennsylvania Press.

Bacchilega, C. (2013). Fairy tales transformed?: Twenty-first-century adaptations and the politics of wonder. Wayne State University Press.

Barthelme, D. (1999). Królewna Śnieżka (K. Fordoński, tłum.). Rebis. (wyd. oryg. 1965).

Bednarek, M. (2011). Ucieczka z zamkowej wieży, czyli o feministycznym prze-pisywaniu baśni w prozie polskiej po 1989 r. Zagadnienia Rodzajów Literackich, 2, 229-249.

Bednarek, M. (2016a). Neopogańskie inspiracje w prozie polskiej na przykładzie Czarownicy $z$ Radosnej Zofii Staniszewskiej. Balkanoslavica, 40-44, 161-167.

Bednarek, M. (2016b). Czar opowieści. Dylogie Catherynne M. Valente oraz Salmana Rushdiego w kontekście Księgi tysiąca i jednej nocy. Poznańskie Studia Polonistyczne. Seria Literacka, 28(48), 183-205.

Bednarek, M. (2017a). Feministyczny czar wiedźmy? Wokół mitu czarownicy w polskiej prozie przełomu XX i XXI. W: A. Anczyk, J. Doroszewska, K. M. Hess (red.), Czarownice. Studia z kulturowej historii fenomenu (s. 113-119). Sacrum. 
Bednarek, M. (2017b). Władca baśni. Wokół polskiej recepcji Cudownego i pożytecznego Bruna Bettelheima. Porównania, 20, 199-218.

Bednarek, M. (2018). Jaś i Małgosia w XXI wieku. O trawestacjach uwspółcześniających baśni w najnowszej literaturze polskiej. Literatura Ludowa, 6, 3-15. https:// doi.org/10.12775/LL.6.2018.001.

Bednarek, M. (2020). Baśni przeobrażone. Transformacje bajki i baśni w polskiej epice po 1989 roku. WN UAM.

Bettelheim, B. (1985). Cudowne i pożyteczne. O znaczeniach $i$ wartościach baśni (D. Danek, tłum., t. 1 i 2). PIW. (wyd. oryg. 1975).

Bożek, R. (2005). Madame Sinobroda. Rebis.

Butenko, B. (1998). Pyś, czyli wiadukt nad chaszczami. Literatura.

Butenko, B. (2008). Krulewna [!] Śnieżka. Miły zbiorek 4 (stownie czterech) nowych-nienowych, niezbyt umoralniajacych bajeczek: myśliwskiej, obuwniczej, wędrownickiej i domyślnej - niedomyślnej!. Nasza Księgarnia.

Butler, J. (2004). Gender is burning. Dylematy przywłaszczenia i subwersji (I. Kurz, tłum.). Panoptikum, 3, 142-154. (wyd. oryg. 1993).

Butler, J. (2008). Uwikłani w płeć. Feminizm i polityka tożsamości (K. Krasuska, tłum.). Wydawnictwo Krytyki Politycznej. (wyd. oryg. 1990).

Całek, A. (2017). Retelling w literaturze fantasy. Od renarracji do metafikcji. W: M. M. Leś, W. Łaszkiewicz, P. Stasiewicz (red.), Tekstowe światy fantastyki (s. 45-66). Prymat, Mariusz Śliwowski.

Carroll, L. (1865). Alice's adventures in Wonderland. Macmillan.

Carter, A. (1978). The bloody chamber. Harper \& Row.

Carter, A. (2000). Czarna Wenus. Opowiadania (A. Ambros, tłum.). Czytelnik.

Czabanowska-Wróbel, A. (1996). Baśń w literaturze Młodej Polski. TAiWPN Universitas.

Czarnecki, Th. (b.d.). From enchantment to down [cykl fotografii]. Pobrane 31 lipca $2020 \mathrm{z}:$ http://www.thomasczarnecki.com/\#/water/.

Ćwiklak, K. (red.). (2014). Baśń we współczesnej kulturze. T.1. Niewyczerpana moc baśni: literatura - sztuka - kultura masowa. WN UAM.

Dmitruk, M. (2003). [cykl fotografii]. Pobrane 31 lipca 2020 z: http://fototapeta.art. pl/2003/kmd.php.

Dukaj, J. (2009). Wroniec. Wydawnictwo Literackie.

Dunin, K. (2020). Ojciec Ziemia jest na nas zły. Krytyka Polityczna. Pobrane 31 lipca 2020 z: https://krytykapolityczna.pl/kultura/czytaj-dalej/kinga-dunin-czyta/ojciec-ziemia-jest-na-nas-zly/.

Dzido, M. (b.d.). Matrioszka. Korporacja Ha!art. Pobrane 31 lipca 2020 z: http:// haart.e-kei.pl/matrioszka/.

Filipiak, I. (1995). Absolutna amnezja. Obserwator. 
Goldstein, D. (2007-2009). Fallen princesses [cykl fotografii]. Pobrane 31 lipca 2020 z: https://www.dinagoldstein.com/dina-goldsteins-fallen-princesses/.

Grass, G. (1995). Turbot (S. Błaut, tłum., M. Janion, wstęp). Polnord, Oskar. (wyd. oryg. 1977).

Greenhill, P. (2020). Reality, magic, and other lies: Fairy-tale film truths. Wayne State University Press.

Greenhill, P., Rudy, J. T. (red.). (2014). Channeling wonder: Fairy tales on television. Wayne State University Press.

Greenhill, P., Rudy, J. T., Hamer, N., Bosc, L. (red.). (2018). The Routledge companion to media and fairy-tale cultures. Routledge.

Grochola, K. (2001). Nigdy wizyciu!. W.A.B.

Haan, L. (2010). Król i król (S. Paszkiet, tłum.). Adpublik. (wyd. oryg. 2000).

Hallett, M., Karasek, B. (2014). Fairy tales in popular culture. Broadview Press.

Haase, D. (2016). Fairy tale. W: A. E. Duggan, D. Haase, H. Callow (red.), Folktales and fairy tales: Traditions and texts from around the world (t. 1, s. 319-322). Greenwood.

Jones, C. A., Schacker, J. (red.). (2013). Marvelous transformations: An anthology of fairy tales and contemporary critical perspectives. Broadview Press.

Joosen, V. (2011). Critical and creative perspectives on fairy tales: An intertextual dialogue between fairy-tale scholarship and postmodern retellings. Wayne State University Press.

Jóźwiak, W. (2015). O dzielnych księżniczkach i pięknych królewiczach. Stowarzyszenie na Rzecz Rozwoju Zdolności Dzieci i Młodzieży im. A. Gołąba.

Karpowicz, I. (2014). Sońka. Wydawnictwo Literackie.

Kérchy, A. (red.). (2011). Postmodern reinterpretations of fairy tales: How applying new methods generates new meanings. Mellen.

Klimek, K. (2011). Baśnie księżniczki popkultury. Dwutygodnik, 72. Pobrane 31 lipca 2020 z: https://www.dwutygodnik.com/artykul/2967-basnie-ksiezniczki-popkultury.html.

Kostecka, W. (2014). Baśń postmodernistyczna: przeobrażenia gatunku. Intertekstualne gry $z$ tradycja literacka. Wydawnictwo SBP.

Kostecka, W. (2016). Baśniowe herstory. Postmodernistyczne strategie reinterpretacyjne Angeli Carter, Tanith Lee i Emmy Donoghue. Creatio Fantastica, 2(53), 23-39.

Kostecka, W. (2017). New subjects, disrupted principles: Fractured fairy tales in a postmodern reality. Selected examples from Poland. W: A. M. Ramos, M. T. Cortez, S. Mourão (red.), Children's literature: Fractures and disruptions (s. 209-227). Cambridge Scholars.

Kostecka, W. (2018). And they lived happily never after: On the anti-utopian function of postmodern Polish fairy tales by Bohdan Butenko, Hanna Krall, and 
Sławomir Shuty. Marvels and Tales, 32(2), 296-313. https://doi.org/10.13110/marvelstales.32.2.0296.

Kowalczyk, K. (2015). Antagoniści we współczesnych renarracjach baśni na przykładzie czarownicy z Jasia i Małgosi braci Grimmów. Przegląd Humanistyczny, 3, 35-46.

Kowalczyk, K. (2016). Baśń w zwierciadle popkultury. Renarracje baśni ze zbioru Kinder- und Hausmärchen Wilhelma i Jakuba Grimmów w przestrzeni popularnej. Stowarzyszenie Badaczy Popkultury i Edukacji Popkulturowej „Trickster”, Polskie Towarzystwo Ludoznawcze.

Krall, H. (1994). Co się stało z nasza bajką? Twój Styl.

Krzyżanowski, J. (red.). (1965). Słownik folkloru polskiego. Wiedza Powszechna.

Kulesza, D. (2013). Genologiczna historia literatury polskiej XX i XXI wieku. W: D. Kulesza (red.), Tradycja i przyszłość genologii (s. 39-65). Wydawnictwo UwB.

Lasoń-Kochańska, G. (2018). Prawda baśni, czyli trudne tematy Agnieszki Suchowierskiej. Annales Universitatis Paedagogicae Cracoviensis. Studia Poetica, 6, 63-73. https://doi.org/10.24917/23534583.6.6.

Leszczyński, G. (1990). Młodopolska lekcja fantazji. O przełomie antypozytywistycznym w literaturze fantastycznej dla dzieci i młodzieży. Instytut Literatury Polskiej UW.

Lurie, A. (1970, 17 grudnia). Fairy tale liberation. New York Review of Books, 42-44.

Ługowska, J. (1981). Ludowa bajka magiczna jako tworzywo literatury. Zakład Narodowy im. Ossolińskich.

Ługowska, J. (1988). Bajka w literaturze dziecięcej. Młodzieżowa Agencja Wydawnicza.

Martin, A. (2006). Red Riding Hood and the wolf in bed: Modernism's fairy tales. University of Toronto Press.

Masłowska, D. (2014). Jak zostałam wiedźmą. Wydawnictwo Literackie.

Matka Bolka [Kozak, B.]. (1993). Bajki. Pełnym Głosem, 1, 141-144.

Mazela, A. (2013). Żywotność baśni braci Grimm w kulturze współczesnej. Na przykładzie fotografii i plakatu. W: W. Kostecka (red.), Grimm: potęga dwóch braci. Kulturowe konteksty Kinder- und Hausmärchen (s. 251-261). Oficyna Wydawnicza ASPRA-JR.

Menzel, I. (2014). Szeptucha. Wydawnictwo MG.

Moraru, C. (2001). Rewriting: Postmodern narrative and cultural critique in the age of cloning. State University of New York Press.

Nasiłowska, A. (2002). Królewna Śnieżka. Fraza, 4, 67-70.

Olech, J. (2008). Ilustracja polska po potopie. W: G. Leszczyński, D. Świerczyńska-Jelonek, M. Zając (red.), Po potopie. Dziecko, ksiażka i biblioteka w XXI wieku. Diagnozy i postulaty (s. 189-194). Wydawnictwo SBP.

Passent, D. (1994). Nareszcie we własnym domu. Wiadomości Kulturalne, 31, dod. Pod Choinke, iii. 
Pawłowska, M., Szamałek, J. (2015). Kim jest ślimak Sam?. Wydawnictwo Krytyki Politycznej.

Pilipiuk, A. (2003). Bajeczka dla wnuczka. W: Kroniki Jakuba Wędrowycza (s. 210220). Fabryka Słów.

Praet, S., Kérchy, A. (red.). (2019). The fairy tale vanguard: Literary self-consciousness in a marvelous genre. Cambridge Scholars.

Propp, V. A. (1976). Morfologia bajki (W. Zagórska, tłum.). Książka i Wiedza. (wyd. oryg. 1928).

Reynolds, K. (2020). The feminist architecture of postmodern anti-tales: Space, time \& bodies. Routledge.

Rusek, M. (2015). W poszukiwaniu baśni o współczesności. Wroniec Jacka Dukaja i Jak zostałam wiedźmą Doroty Masłowskiej. W: B. Niesporek-Szamburska, M. Wójcik-Dudek, A. Zok-Smoła (red.), (Przed)szkolne spotkania z lektura (s. 303-313). Wydawnictwo UŚ.

Rusinek, M. (2006). Kopciuszek. Jacek Santorski \& Co.

Saint-Gelais, R. (2011). Fictions transfuges. La transfictionnalité et ses enjeux. Éditions du Seuil.

Saramonowicz, M. (1996). Siostra. W.A.B.

Schanoes, V. L. (2014). Fairy tales, myth, and psychoanalytic theory: Feminism and retelling the tale. Ashgate.

Shuty, S. (2012). Kopciuszek idzie na wojne, czyli historia kołem się toczy. Bunkier Sztuki. Sieniewicz, M. (2010). Miasto Szklanych Słoni. Znak.

Skowera, M. (2012). Baśnie na czas kryzysu. Rzecz o konferencji naukowej Grimm² potęga dwóch braci. W dwusetna rocznice pierwszego wydania Kinder- und Hausmärchen. StRuNa - Biuletyn Młodych Naukowców, 1, 28-35.

Skowera, M. (2014). Cudowna i pożyteczna Magda Gessler. O strukturze, znaczeniach i wartościach „telewizyjnej baśni”. W: M. Błaszkowska, K. Kleczkowska, A. Kuchta, M. Kuster, J. Malita, P. Pawlak, I. Pisarek, P. Waczyński (red.), Kultura jedzenia, jedzenie w kulturze (s. 196-205). AT Wydawnictwo.

Skowera, M. (2016). Postmodernistyczny retelling baśni - garść uwag terminologicznych. Creatio Fantastica, 2(53), 41-56.

Sławiński, B. (2008). Królowa Tiramisu. Warszawa: Jacek Santorski \& Co.

Smith, K. P. (2007). The postmodern fairytale: Folkloric intertexts in contemporary fiction. Palgrave Macmillan.

Stefaniak-Maślanka, B. (2015). Baśń, storytelling i popkultura. W: M. Kocot, K. Szafraniec (red.), Języki (pop)kultury w literaturze, mediach i filmie (s. 191-201). Wydawnictwo UŁ. https://doi.org/10.18778/8088-061-0.18.

Suchowierska, A., Eichelberger, W. (2012). Królewicz Śnieżek. Baśniowe stereotypy płci. Bajki na opak. Czarna Owca. 
Sztybor, B., Nowacki, P., Mazur, Ł. (2016). Niebieska Kapturka. Tashka.

Szwaja, M. (2005). Stateczna i postrzelona. Prószynski i S-Ka.

Terakowska, D. (2003). Babci Brygidy szalona podróż po Krakowie. Jeden dzień czarownicy. Jedna noc czarownicy. Wydawnictwo Literackie.

Tiffin, J. (2009). Marvelous geometry: Narrative and metafiction in modern fairy tale. Wayne State University Press.

Tokarczuk, O. (1996). Prawiek i inne czasy. W.A.B.

Tokarczuk, O. (2009). Prowadźswój pług przez kości umarlych. Wydawnictwo Literackie.

Turner, K., Greenhill, P. (red.). (2012). Transgressive tales: Queering the Grimms. Wayne State University Press.

Wajda, M. (b.d.). Współczesne Kopciuszki. Pro Libris. Lubuskie Pismo Literacko-Kulturalne. Pobrane 31 lipca $2020 \mathrm{z}$ : http://prolibris.net.pl/varia/1122-wspolczesne-kopciuszki.

Waksmund, R. (1978). Bajkosfera, czyli o użyciu semiotycznym fabuł baśniowych. Rekonesans badawczy. Litteraria, 9, 99-119.

Waksmund, R. (1998). Wstęp. W: R. Waksmund (wyb. i opr.), Gabinet wróżek. Antologia baśni francuskiej XVII-XVIII wieku (s. 5-28). Wacław Bagiński.

Waksmund, R. (2000). Od literatury dla dzieci do literatury dziecięcej (tematy - gatun$k i-k o n t e k s t y)$. Wydawnictwo UWr.

Waksmund, R. (2005). Baśń sponiewierana (Kartka z dziejów gatunku). W: G. Leszczyński (red.), Kulturowe konteksty baśni. Tom 1. Rozigrana córa mitu (s. 38-55). Centrum Sztuki Dziecka.

Walentynowicz, D. (2005). Bajki [cykl fotografii]. Pobrane 31 lipca 2020 z: https:// www.swiatobrazu.pl/bajki_doroty_walentynowiczjuprbkym.html.

Adamson, A., Jenson, V. (reż.). (2001). Shrek [film]. DreamWorks.

Wróblewska, V. (2016-2018). Baśń. W: V. Wróblewska (red.), Słownik polskiej bajki ludowej. Pobrane 31 lipca 2020 z: https://bajka.umk.pl/slownik/lista-hasel/haslo/?id=225.

Wróblewska, V. (2003). Przemiany gatunkowe polskiej baśni literackiej XIX i XX wie$k u$. Adam Marszałek.

Wróblewska, V. (2014). Od potworów do znaków pustych. Ludowe demony w polskiej literaturze dla dzieci. WN UMK.

Zipes, J. (1986). Introduction. W: Don't bet on the prince: Contemporary feminist fairy tales in North America and England (s. 1-38). Gower.

Zipes, J. (2006). Why fairy tales stick: The evolution and relevance of a genre. Routledge. 